\title{
Pelatihan Penggunaan Google Classroom dan Google Meet bagi Tenaga Pendidik SMP di Kabupaten Sumba Timur
}

Erwin Randjawali*, Mayun Erawati $\mathrm{Nggaba}^{2}$, Anggriati Ledu Ngaba ${ }^{3}$, Yuliana Tamu Ina Nuhamara ${ }^{4}$, Elsy S. H. Taunu ${ }^{5}$, Darius Imanuel Wadu ${ }^{6}$, Stevvileny Angu Bima7, Iona Lisa Ndakularak ${ }^{8}$, Yuliana S Eko 9 , Mega Retno Wulandari10, Itha Priyastity ${ }^{11}$, Irna Natalis Sanit ${ }^{12}$

\author{
1,2,3,4,5,6,7,8,9,10,11,12 Universitas Kristen Wira Wacana Sumba, Waingapu, Indonesia \\ *Corresponding Author: erwinrandjawali@unkriswina.ac.id \\ Info Artike \\ Diterima : $16 / 11 / 2021$ \\ Direvisi: $18 / 11 / 2021$ \\ Disetujui: $22 / 11 / 2021$
}

\begin{abstract}
The implementation of this Community Service activity is motivated by the problems experienced by partners at SMP Kristen Payeti. The teachers in that school have not been able to take advantage of online learning applications such as Google Classroom and Google Meet. Therefore, to overcome the partner's problems, training was carried out by the PkM Team of Program Studi Pendidikan Matematika Universitas Kristen Wira Wacana Sumba, which aims to educate the teachers so that they can increase their knowledge and skills related to the use of the two applications. The training activities were carried out using lectures, demonstrations, and simulations using Google Classroom and Google Meet. While the stages of implementation include the preparation of training modules, preparation of training rooms, and implementation of training. The results of this service activity indicate that there is an increase in the knowledge and skills of teachers as trainees in using the two applications. Thus it can be concluded that the purpose of this service activity has been achieved. The follow-up carried out was to monitor the use of these two applications by teachers in the implementation of online learning.
\end{abstract}

Keywords: Classroom, Meet, Service activity

\begin{abstract}
Abstrak. Pelaksanaan kegiatan Pengabdian kepada Masyarakat ini dilatar belakangi oleh permasalahan yang dialami mitra di SMP Kristen Payeti yakni para guru belum dapat memanfaatkan aplikasi pembelajaran daring seperti Google Classroom dan Google Meet. Oleh karena itu, untuk mengatasi permasalahan mitra tersebut dilakukan pelatihan oleh Tim PkM Prodi Pendidikan Matematika Universitas Kristen Wira Wacana Sumba yang bertujuan untuk mengedukasi para guru tersebut sehingga dapat meningkatkan pengetahuan serta keterampilan terkait penggunaan kedua aplikasi tersebut. Kegiatan pelatihan dilaksanakan dengan metode ceramah, demonstrasi, serta simulasi penggunaan Google Classroom dan Google Meet. Sedangkan tahapan pelaksanaan yang dilakukan meliputi penyusunan modul pelatihan, persiapan ruang pelatihan, dan pelaksanaan pelatihan. Hasil dari kegiatan pengabdian ini menunjukkan bahwa terjadinya peningkatan pengetahuan dan keterampilan para guru sebagai peserta pelatihan dalam menggunakan kedua aplikasi tersebut. Dengan demikian dapat disimpulkan bahwa tujuan kegiatan pengabdian ini telah tercapai. Adapun tindak lanjut yang dilakukan adalah melakukan monitoring terkait pemanfaatan kedua aplikasi tersebut oleh para guru dalam pelaksanaan pembelajaran daring.
\end{abstract}

Kata Kunci: Classroom, Meet, Pengabdian.

How to Cite: Randjawali, E., Nggaba, M. E., Ngaba, A. L., Nuhamara, Y. T. I., Taunu, E. S.H., Wadu, D. I., Bima, S. A., Ndakularak, I. L., Eko, Y. S., Wulandari, M. R., Priyastity, I., \& Sanit, I. N. (2021). Pelatihan Penggunaan Google Classroom dan Google Meet bagi Tenaga Pendidik SMP di Kabupaten Sumba Timur. Prima Abdika: Jurnal Pengabdian Masyarakat, 1(4), 206-212. https:// doi.org/ 10.37478/abdika.v1i4.1332

Copyright (c) 2021 Erwin Randjawali, Mayun Erawati Nggaba, Anggriati Ledu Ngaba, Yuliana Tamu Ina Nuhamara, Elsy S. H. Taunu, Darius Imanuel Wadu, Stevvileny Angu Bima, Iona Lisa Ndakularak, Yuliana S Eko, Mega Retno Wulandari, Itha Priyastity, Irna Natalis Sanit. This work is licensed undera Creative Commons Attribution-ShareAlike 4.0 International License.

\section{Pendahuluan}

Dalam rangka mengembangkan pendidikan di masyarakat, perlu adanya upaya melaksanakan kegiatan pengabdian kepada masyarakat (PkM). Kegiatan ini bertujuan untuk meningkatkan kualitas sumber daya manusia serta sebagai bagian dari tugas dan tanggung jawab dosen dalam pengembangan Tridharma PT yaitu pendidikan, penelitian, dan PkM.Menurut Sagajoka et al., (2021) melalui kegiatan PkM dapat membantu masyarakat 
dalam pengembangan skill dan pengetahuan. Selain itu menurut Pujianti, (2020) manfaat langsung dari kegiatan PKM adalah mampu menjawab masalah yang sedang dihadapi masyarakat dengan memberikan pelatihan atau sosialisasi kepada masyarakat. Oleh karena itu, kegiatan PkM sangat membantu dalam menyelesaikan masalah yang sedang terjadi di masyarakat.

Di masa pandemi Covid-19 saat ini, terdapat banyak permasalahan yang muncul di tengah masyarakat termasuk di dunia pendidikan. Salah satu masalah yang muncul di dunia pendidikan adalah masalah pelaksanaan pembelajaran dalam jaringan (daring). Masalah yang terjadi yakni penyesuaian penggunaan media pembelajaran dalam melaksanakan pembelajaran di masa pandemi Covid-19. Dalam rangka pembelajaran daring, guru dituntut harus dapat menggunakan media pembelajaran berbasis online. Menurut Pujiyanti \& Mulyawati, (2021) melalui penggunaan media pembelajaran online secara efektif dapat membantu pembelajaran daring atau pembelajaran jarak jauh, berjalan lancar dan pembelajaran dapat dengan baik dilaksanakan.

Masalah terkait pembelajaran daring tersebut juga di temukan di SMP Kristen Payeti. Berdasarkan observasi awal yang dilakukan pada tanggal 13 November 2020 dan hasil wawancara kepada Kepala SMP Kristen Payeti, diketahui bahwa guru-guru mengalami kesulitan dalam pembelajaran daring. Selama pembelajaran daring, para guru di sekolah tersebut menggunakan Google Drive dan WhatsApp Group untuk mengumpulkan tugas. Namun dalam pelaksanaannya, terdapat banyak siswa yang mengirimkan tugas berulang kali. Hal ini berdampak pada proses memilah data yang memakan waktu dan proses koreksi tugas pun harus berulang jika guru teledor mengeliminasi lembar jawaban yang dikirimkan berulang oleh siswa. Dengan demikian waktu untuk mengoreksi tugas menjadi tidak efektif dan menyebabkan guru bekerja lebih ekstra. Ningsih et al., (2020) menemukan bahwa salah satu problematika yang dialami guru dalam menggunakan teknologi informasi dan komunikasi di sekolah yaitu menguras waktu. Sejalan dengan penelitian tersebut, hasil penelitian yang dilakukan Syaiful et al., (2021) menunjukkan bahwa efektivitas pembelajaran secara daring selama masa pandemi Covid-19 yang dilakukan oleh siswa dan guru kurang efektif.

Selain masalah yang ditemui ketika menggunakan Google Drive, masalah lain juga ditemukan ketika menggunakan WhatsApp Group. Jawaban yang dikirim siswa menumpuk, sedangkan kapasitas penyimpanan pada smartphone para guru masih belum memadai, sehingga menyebabkan banyak tugas dan file lain tidak terdokumentasi dengan baik. Permasalahan terakhir yang tidak kalah penting yaitu masih banyak guru yang belum menguasai teknologi informasi. Hal ini menyebabkan guru kurang optimal dalam menyampaikan materi, kurang berkomunikasi serta bersosialisasi dengan para siswa (Baalwi, 2020).

Berdasarkan permasalahan-permasalahan yang dihadapi oleh mitra, maka program studi Pendidikan Matematika Universitas Kristen Wira Wacana Sumba melakukan kegiatan pengabdian kepada masyarakat di SMP Kristen Payeti sebagai salah satu sekolah mitra berupa pelatihan penggunaan Google Classroom dan Google Meet kepada guru-guru di sekolah tersebut. Pelatihan ini diharapkan dapat mengedukasi guru-guru SMP Kristen Payeti dalam 
menggunakan Google Classroom dan Google Meet. Hal ini dapat meningkatkan kemampuan guru dalam menggunakan teknologi dalam pembelajaran.

Aplikasi Google Classroom memiliki beberapa kelebihan. Misalkan aplikasi tersebut tidak berbayar, dapat gunakan di laptop dan smartphone (Hapsari, 2019). Selain itu, terdapat fitur materi dan kolom pengumpulan tugas, sehingga memiliki tampilan yang rapih. Selain itu, terdapat pula rubrik penilaian yang dapat mempersingkat waktu koreksi.

\section{Metode Pelaksanaan}

Terdapat beberapa tahapan yang dilakukan dalam proses pelaksanaan pelatihan Google Classroom dan Google Meet. Tahapan pertama yaitu pembuatan modul: pada tahap ini, dibuat modul pelatihan google classroom oleh tim pengabdian kepada masyarakat $(\mathrm{PkM})$. Tahapan yang kedua yaitu persiapan tempat pelatihan: pada tahap ini, tim PkM mempersiapkan ruangan pelatihan di SMP Kristen Payeti. Misalnya mempersiapkan spanduk, LCD, meja, kursi dan memastikan jarak tempat duduk untuk masing-masing peserta agar memenuhi protokol kesehatan yang dianjurkan oleh pemerintah. Tahap terakhir yaitu pelaksanaan kegiatan pelatihan Google Classroom dan Google Meet di lokasi PkM.

Adapun metode yang digunakan dalam pelaksanaan pelatihan Google Classroom dan Google Meet yaitu ceramah, demonstrasi penggunaan aplikasi dan yang terakhir adalah simulasi penggunaan aplikasi. Metode yang pertama adalah ceramah. Ceramah digunakan untuk mempresentasikan materi Google Classroom dan Google Meet secara keseluruhan. Mulai dari pengenalan aplikasi, fitur-fitur yang terdapat dalam aplikasi, dan pembuatan akun Google Classroom dan Google Meet bagi guru-guru. Metode demonstrasi dilakukan untuk memperagakan penggunaan aplikasi Google Classroom dan Google Meet. Pada metode yang terakhir adalah simulasi yang dilakukan untuk mendampingi guru-guru dalam mempraktikkan penggunaan aplikasi Google Classroom dan Google Meet, mencoba fitur-fitur yang tersedia, hingga membuat Meeting dan mengundang peserta lain bergabung dalam meeting tersebut. Proses pelatihan ini dilakukan dengan mentaati protokol kesehatan sesuai anjuran pemerintah.

\section{Hasil dan Pembahasan}

Pelaksanaan kegiatan pelatihan penggunaan Google Classroom bagi para guru SMP Kristen Payeti dilaksanakan pada tanggal 8 Januari 2021 bertempat di Aula SMP Kristen Payeti. Pelatihan ini dihadiri oleh 30 orang guru SMP Kristen Payeti dan Tim PkM Program Studi Pendidikan Matematika Unkriswina Sumba. Kegiatan pelatihan juga dilakukan dengan tetap memperhatikan protokol kesehatan untuk mencegah penyebaran pandemi Covid-19.

Adapun fokus materi yang disajikan dalam pelatihan ini adalah cara penggunaan Google Classroom yang meliputi: fitur-fitur yang disediakan oleh Google Classroom, pembuatan akun di Google Classroom, penambahan kelas, penambahan peserta didik maupun guru mata pelajaran, pengiriman materi, pembuatan tugas, pembuatan kuis, pembuatan rubrik penilaian, dan penilaian peserta didik secara langsung di Google Classroom. Pemilihan materi tersebut telah disesuaikan dengan permasalah mitra yang diperoleh melalui survey awal kepada Kepala SMP Kristen Payeti. Seperti telah dijelaskan pada 
bagian pendahuluan bahwa tidak semua guru di sekolah tersebut memiliki pengetahuan maupun keterampilan yang memadai terkait penggunaan IT dalam pembelajaran daring. Sehingga, dengan menguasai materi-materi tersebut dan mempraktekkannya secara langsung, maka para guru dapat memperoleh pengetahuan dan keterampilan yang dapat dipergunakan untuk melaksanakan pembelajaran daring (online). Hal ini penting karena menurut hasil penelitian, penggunaan Google Classroom dapat meningkatkan motivasi serta hasil belajar peserta didik (Nirfayanti \& Nurbaeti 2019). Meskipun demikian, salah satu kendala yang mungkin dihadapi oleh peserta didik dan guru dalam pembelajaran daring adalah ketersediaan internet .

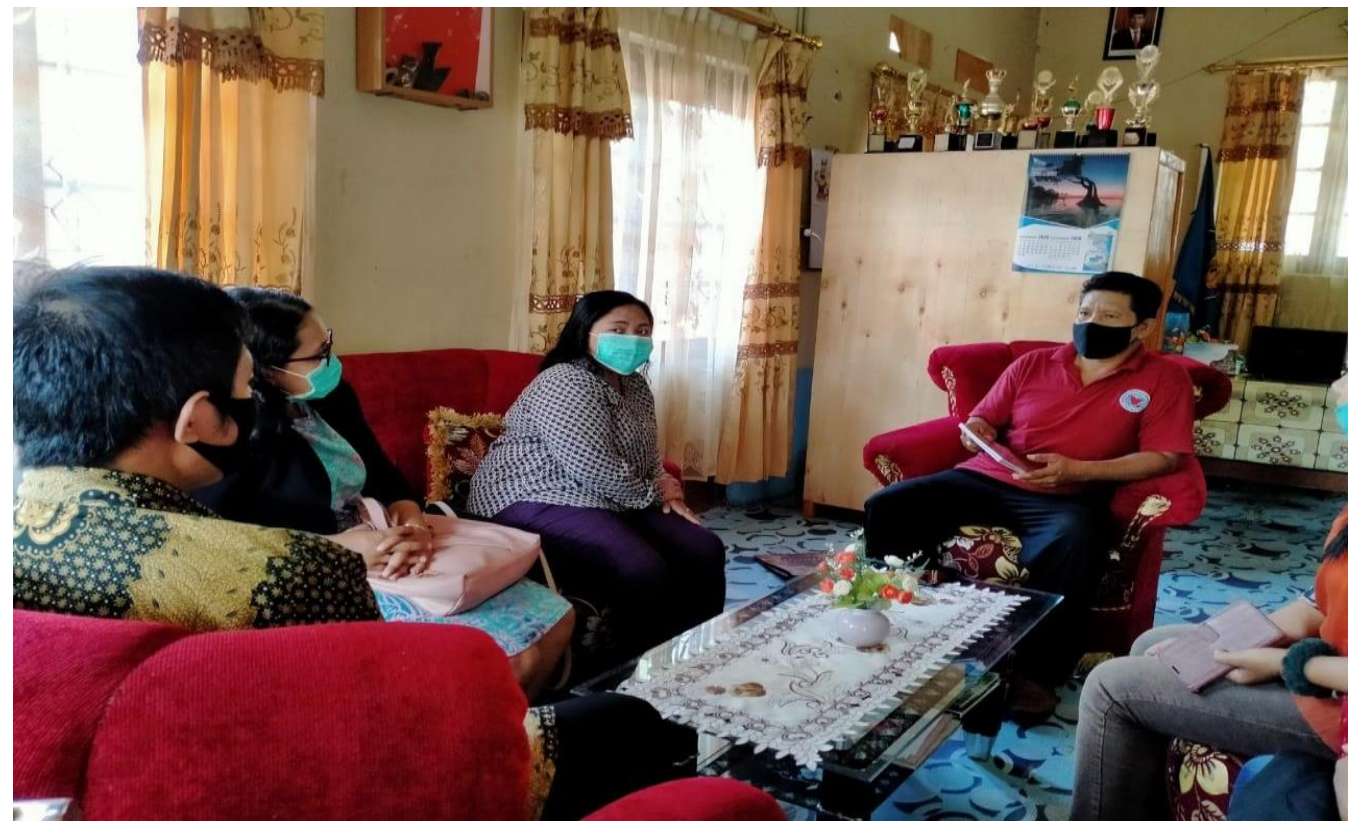

Gambar 1. Survey awal yang dilakukan untuk mengetahui permasalahan mitra

Pelatihan ini tidak hanya menyajikan materi tentang Google Classroom tetapi juga terkait fitur-fitur yang tersedia pada Google Meet serta penggunaan Google Meet sebagai sarana pembelajaran tatap muka secara daring di masa pandemi. Penggunaan Google Meet ini memungkinkan para guru dan peserta didik untuk tetap berinteraksi secara langsung pada saat penjelasan materi pembelajaran walaupun harus dilakukan secara daring. Kelebihan lainnya dari aplikasi ini adalah dapat dilakukannya diskusi untuk menjelaskan materi secara lebih mendetail (Pernantah, Nova, \& Annisa Suci Ramadhani, 2021).

Materi-materi yang telah disebutkan di atas disajikan dalam bentuk presentasi oleh Tim PkM Prodi Pendidikan Matematika Unkriswina Sumba. Penyajian materi tersebut disertakan langsung dengan demonstrasi penggunaan Google Classroom dan Google Meet sehingga dapat dipraktikkan oleh peserta pelatihan. Kegiatan tersebut dapat diikuti dengan baik oleh peserta pelatihan. Peserta kegiatan selanjutnya melakukan simulasi pembuatan contoh kelas mata pelajaran sesuai dengan bidang ilmu yang diampu. Peserta juga melakukan simulasi lain di Google Classroom seperti membagikan link kelas Google Classroom, menambah peserta kelas, mengupload tugas, mengupload materi, membuat kuis, menambahkan rubrik pada tugas online, menilai tugas secara online, dan lain-lain. Selain itu, 
peserta juga melakukan simulasi pembelajaran tatap muka secara daring dengan menggunakan Google Meet, belajar terkait cara mempresentasikan slide pembelajaran maupun video secara daring, dan bahkan cara merekam pembelajaran yang sedang berlangsung melalui aplikasi tersebut.

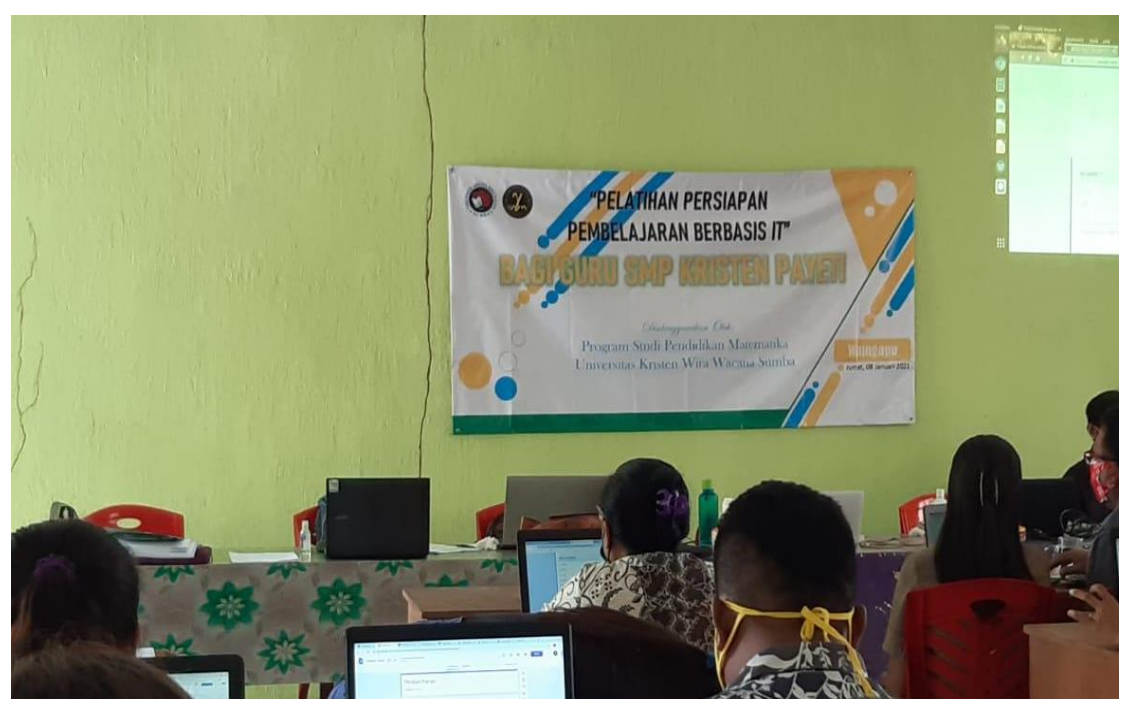

Gambar 2. Peserta pelatihan sedang mempraktekkan cara penggunaan Google Classroom dan Google Meet

Dalam pelatihan tersebut, peserta pelatihan sangat aktif dalam mengikuti arahan yang diberikan oleh Tim PkM Prodi Pendidikan Matematika Unkriswina Sumba. Hampir sebagian peserta dapat mempraktikkan hal-hal yang didemonstrasikan oleh Tim PkM. Akan tetapi, masih didapati beberapa peserta pelatihan yang masih mengalami kesulitan dalam menggunakan kedua aplikasi tersebut. Meskipun demikian, hal ini telah dapat diperbaiki melalui pendampingan secara langsung oleh para anggota Tim PkM di tempat duduk peserta PkM yang mengalami kendala tersebut.

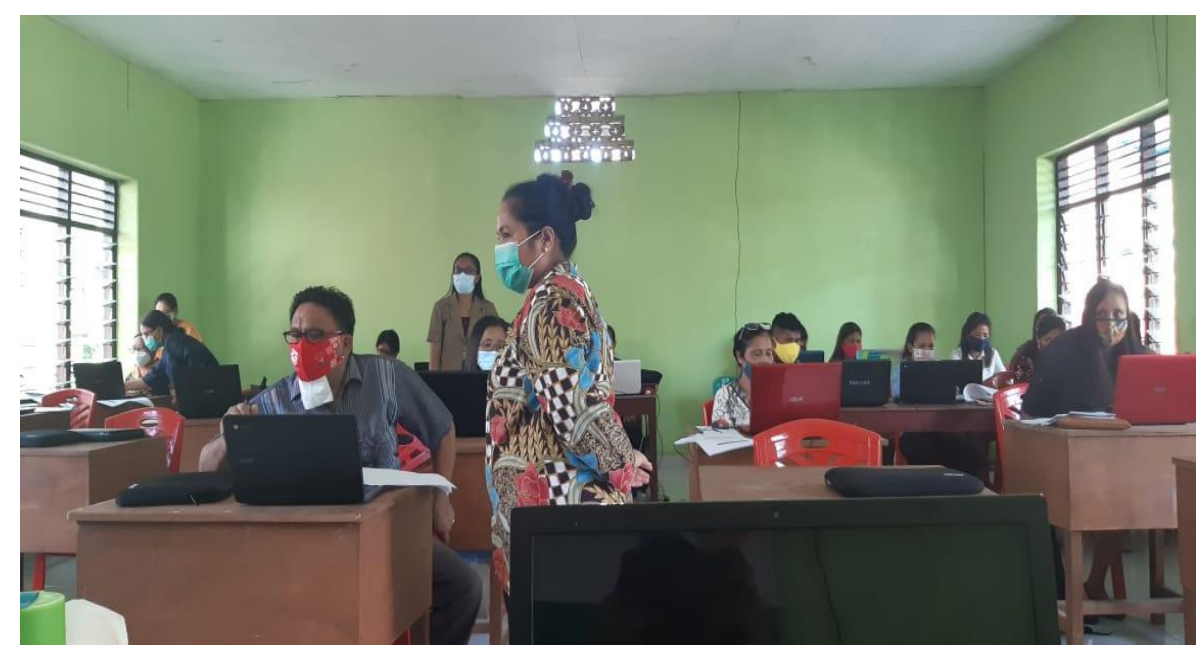

Gambar 3. Peserta pelatihan sedang mempraktekkan cara penggunaan Google Classroom dan Google Meet

Berdasarkan pengamatan yang dilakukan oleh Tim PkM terhadap peserta pelatihan selama proses simulasi penggunaan Google Classroom dan Google Meet berlangsung, terlihat bahwa telah terjadi peningkatan 
pengetahuan terkait fitur-fitur yang disediakan pada kedua aplikasi tersebut serta cara penggunaannya. Peningkatan pengetahuan tersebut juga turut mempengaruhi keterampilan peserta pelatihan dalam menggunakan kedua aplikasi tersebut. Peningkatan keterampilan tersebut ditunjukkan melalui antusias para peserta pelatihan untuk mengembangkan lebih lanjut kelas yang telah dibuat pada saat simulasi, sehingga dapat langsung dipergunakan pada saat proses pembelajaran di pertemuan berikutnya. Dengan demikian, kegiatan pengabdian ini telah mencapai tujuan pelaksanaan PkM.

\section{Simpulan dan Tindak Lanjut}

Pelatihan Google Classroom dan Google Meet oleh Tim PkM Prodi Pendidikan Matematika Universitas Kristen Wira Wacana Sumba telah meningkatkan pengetahuan para guru di SMP Kristen terkait fitur-fitur pada aplikasi tersebut serta cara menggunakan kedua aplikasi tersebut. Selain itu, pelatihan ini telah meningkatkan keterampilan para guru di SMP Kristen Payeti dalam menggunakan aplikasi pembelajaran berbasis IT secara online. Dengan demikian, proses pembelajaran daring di sekolah tersebut telah dapat diselenggarakan dengan baik. Adapun tindak lanjut yang dilakukan dari kegiatan pendampingan ini proses monitoring penggunaan Google Classroom dan Google Meet oleh guru sehingga dapat membantu para guru yang mengalami kendala dalam menerapkan penggunaan kedua aplikasi tersebut dalam proses pembelajaran daring secara riil kepada peserta didik.

\section{Daftar Pustaka}

Baalwi, M. A. (2020). Kendala Guru Dalam Proses Pembelajaran Online Selama Masa Pandemi Ditinjau Dari Kemajuan Information Technology [IT] Guru. Lintang Songo: Jurnal Pendidikan, 3 Nomor 2, 38-45.

Hapsari, S. A. (2019). Pemanfaatan Google Classroom Sebagai Media Pembelajaran Online Di Universitas Dian Nuswantoro. WACANA, 18 Nomor 2, 225-233.

Ningsih, S., Kuntarto, E., \& Kurniawan, A. R. (2020). TEACHERS' PROBLEMS IN USING INFORMATION AND COMMUNICATION TECHNOLOGY (ICT) AND ITS IMPLICATIONS IN ELEMENTARY SCHOOLS. Pajar [Pendidikan Dan Pengajaran], 4 Nomor 3, 518-524.

Nirfayanti, \& Nurbaeti. (2019). Pengaruh Media Pembelajaran Google Classroom Dalam Pembelajaran Analisis Real Terhadap Motivasi Belajar Mahasiswa. Proximal: Jurnal Penelitian Matematika Dan Pendidikan Matematika, 1 Nomor 2, 50-59. https://ejournal.my.id/proximal/article/view/211/173

Pernantah, P. S., Nova, \& Annisa Suci Ramadhani. (2021). Penggunaan Aplikasi Google Meet Dalam Menunjang Keefektifan Belajar Daring Masa Pandemi Covid-19 di SMA Negeri 3 Pekanbaru. Pedagogi: Jurnal Ilmu Pendidikan, 21 Nomor 1 , 45-50. http:/ / pedagogi.ppj.unp.ac.id/index.php/pedagogi/article/view/991/298

Pujianti, D. co. (2020). Manfaat Besar Pengabdian Kepada Masyarakat [PKM] Dosen. https://www.duniadosen.com/pengabdian-masyarakat-dosen /

Pujiyanti, D., \& Mulyawati, I. (2021). Pelatihan Penggunaan Media 
Pembelajaran Berbasis Online Bagi Guru Terdampak Covid-19 di SMPN 126 Jakarta. Jurnal Solma, 10, 170-178. https://journal.uhamka.ac.id/index.php/solma/article/view/5028/2272

Sagajoka, E., Nona, R. V., Antonia, Y. N., \& Gobhe, D. (2021). Peningkatan Ekonomi Masyarakat Desa Borani Melalui Inovasi Pengolahan Kripik Batang Pisang [BAPIS]. Prima Abdika, Jurnal Pengabdian Masyarakat, 1 Nomor 4, 136-143. https://ejournal.uniflor.ac.id/index.php/abdika/article/view/1257/1134

Syaiful, N., Rudiyansyah, \& Sri Lestari Aslam. (2021). Efektifitas Pembelajaran Daring Selama Masa Pandemi Covid-19 [Studi Kasus Pada Mata Pelajaran Sosiologi di SMAN 20 Gowa]. Equilibrium: Jurnal Pendidikan, 9(1), 86-92. 